\title{
Działalność badawczo-rozwojowa przedsiębiorstw w Polsce na tle Unii Europejskiej
}

Kamil Kwiecień*

\section{Wstęp}

Zmiany zachodzące w gospodarce w ostatnich latach zwracają uwagę na znaczenie poziomu innowacyjności w przedsiębiorstwach. W wyniku tych zmian konieczne staje się uwzględnienie w zarządzaniu podejścia zorientowanego na innowacyjność organizacji. Powinna ona zostać trwale wpisana w system zarządzania oraz kulturę, a także stanowić główną siłę kreatywną przedsiębiorstwa. Działalność innowacyjną uznaje się za niepodważalny atut i jeden z elementów tworzenia wartości rynkowej (Barańska-Fischer i in. 2016, s. 8-10).

Innowacyjność to ważny aspekt funkcjonowania przedsiębiorstw, jednak wzrasta także jej znaczenie jako czynnika wpływającego na rozwój gospodarek narodowych (Tidd, Bessant 2011, s. 25). Innowacyjna gospodarka charakteryzuje się zdolnością do tworzenia oraz wdrażania innowacji, rozumianej jako możliwość opracowywania nowatorskich rozwiązań czy jako całkowity rezultat działalności innowacyjnej podmiotów, które obejmuje dana gospodarka (Weresa 2014, s. 22-23). Działania takie jak modernizacja i rozwój technologii wykorzystywanych w produkcji oraz procesów usługowych, stosowanie nowych rozwiązań w zakresie organizacji i zarządzania czy doskonalenie infrastruktury związanej z gromadzeniem, przetwarzaniem i rozpowszechnianiem informacji wpływają na potencjał konkurencyjny przedsiębiorstw, a jednocześnie na koniunkturę gospodarczą poszczególnych regionów oraz całego kraju.

Jest wiele mierników służących do oceny innowacyjności gospodarki. Do najważniejszych i najczęściej używanych można zaliczyć wskaźniki dotyczące działalności badawczo-rozwojowej. Pozostałe wyznaczniki innowacyjności to m.in. liczba wynalazków czy aktywność patentowa (Dolińska 2010, s. 22-23).

\footnotetext{
${ }^{*}$ Kamil Kwiecień - student, Politechnika Częstochowska, Wydział Zarządzania, Finanse i rachunkowość, kamilkwiecien94a@gmail.com.
} 
Celem artykułu jest analiza struktury i wielkości nakładów na działalność badawczo-rozwojową w Polsce, ze szczególnym uwzględnieniem sektora przedsiębiorstw, w odniesieniu do Unii Europejskiej.

\section{Istota działalności badawczo-rozwojowej}

Organizacja Współpracy Gospodarczej i Rozwoju (OECD) definiuje działalność badawczo-rozwojową (B+R) jako pracę twórcza podejmowana w sposób systematyczny w celu zwiększenia zasobów wiedzy, w tym wiedzy o człowieku, kulturze i społeczeństwie, oraz wykorzystanie tych zasobów wiedzy do tworzenia nowych zastosowań. W działalności B+R można wyróżnić trzy kategorie: badania podstawowe, badania stosowane oraz prace rozwojowe (OECD 2010, s. 34). W tabeli 1 scharakteryzowano wymienione rodzaje działalności $\mathrm{B}+\mathrm{R}$.

Tabela 1. Rodzaje działalności badawczo-rozwojowej

\begin{tabular}{|l|l|}
\hline Rodzaj działalności B+R & Charakterystyka \\
\hline Badania podstawowe & $\begin{array}{l}\text { Prace eksperymentalne oraz teoretyczne, które podejmuje się } \\
\text { głównie w celu pozyskania nowej wiedzy, nie skupiając się na jej } \\
\text { konkretnym zastosowaniu lub wykorzystaniu. Obejmują analizę } \\
\text { własności, zależności i struktur, mają na celu formułowanie i te- } \\
\text { stowanie hipotez, praw i teorii. }\end{array}$ \\
\hline Badania stosowane & $\begin{array}{l}\text { Prace badawcze zmierzające do zdobycia nowej wiedzy, } \\
\text { z uwzględnieniem realizacji konkretnych celów praktycznych. } \\
\text { Opierają się na istniejącej wiedzy oraz rozszerzają ją, by rozwią- } \\
\text { zać konkretne problemy. }\end{array}$ \\
\hline Prace rozwojowe & $\begin{array}{l}\text { Systematyczna praca, której podstawą jest wiedza uzyskana } \\
\text { w toku procesu badawczego i doświadczeń praktycznych. Celem } \\
\text { prac rozwojowych jest wytworzenie nowych produktów, mate- } \\
\text { riałów czy urządzeń, a także udoskonalanie istniejących oraz ini- } \\
\text { cjowanie nowych usług, procesów i systemów. }\end{array}$ \\
\hline
\end{tabular}

Źródło: opracowanie własne na podstawie OECD (2010), Podręcznik Frescati 2002. Proponowane procedury standardowe dla badań statystycznych $w$ zakresie działalności badawczo-rozwojowej, Ministerstwo Nauki i Szkolnictwa Wyższego, s. 89-91.

Działalność badawczo-rozwojowa zajmuje ważne miejsce w polityce innowacyjnej Unii Europejskiej. W 2010 roku Komisja Europejska opublikowała strategię „Europa 2020”, która jest programem inteligentnego oraz zrównoważonego rozwoju na lata 2010-2020. Realizacja strategii zakłada przyjęcie trzech priorytetów: rozwoju inteligentnego (gospodarka oparta na wiedzy i innowacjach), rozwoju zrównoważonego (odpowiednie korzystanie z zasobów naturalnych i troska 
o środowisko naturalne) oraz rozwoju, który wspiera włączenie społeczne (poprawa poziomu zatrudnienia i spójności społeczno-gospodarczej) (Żmuda 2011, s. 205). Powodzenie strategii uzależniono od osiągnięcia kilku mierzalnych celów opartych na wiarygodnych danych. Jednym $\mathrm{z}$ nich jest inwestowanie w działalność $\mathrm{B}+\mathrm{R}$ na poziomie 3\% PKB. Cel zwraca uwagę na konieczność poprawy warunków działalności badawczo-rozwojowej w Unii Europejskiej prowadzonej przez sektor prywatny (Komisja Europejska 2010, s. 12). Polska jako cel krajowy strategii „Europa 2020” przyjęła poziom nakładów na działalność badawczo-rozwojową w wysokości 1,7\% PKB (Gasz 2014, s. 87).

Realizacja badań naukowych i prac rozwojowych odbywa się zarówno w przedsiębiorstwach, jak i poza nimi. Działalność B+R odgrywa jednak kluczową rolę wewnątrz przedsiębiorstw, ponieważ pełni ważną funkcję $\mathrm{w}$ procesach innowacyjnych. Wynika to m.in. z tego, że (Jasiński 2014, s. 66):

1. najefektywniej wdraża się pomysły własne;

2. istnieje bezpośredni związek pomiędzy działalnością badawczo-rozwojową przedsiębiorstwa a pojawiającą się w tym przedsiębiorstwie innowacją;

3. w pracach $\mathrm{B}+\mathrm{R}$ prowadzonych $\mathrm{w}$ przedsiębiorstwach kładzie się nacisk na ich praktyczne wykorzystanie oraz dostosowanie do potrzeb i wymagań rynku.

Biorąc pod uwagę specyfikę działalności B+R, należy zauważyć, że z jednej strony może być ona źródłem wyraźnych korzyści, ale z drugiej - poważnym obciążeniem. Prowadzenie działalności badawczo-rozwojowej wiąże się z koniecznością ponoszenia znacznych kosztów, szczególnie finansowych, a ponadto charakteryzuje się wysokim ryzykiem. W przypadku procesu badawczego, który zakończy się niepowodzeniem, zwrot może nigdy nie nastąpić albo korzyści będą zdecydowanie mniejsze niż oczekiwano. Należy również zwrócić uwagę na trudności, jeśli chodzi o określenie momentu, w którym wyniki prowadzonych prac będą możliwe do wdrożenia. W konsekwencji działalność badawczo-rozwojowa nie jest często wykorzystywanym źródłem innowacji w polskich przedsiębiorstwach. Warto jednak zaznaczyć, że prace B+R - także te, które nie zakończyły się sukcesem - zwiększają zasób wiedzy organizacji (Knosala i in. 2014, s. 221).

\section{Struktura podmiotowa nakładów na działalność badawczo-rozwojową}

Nakłady na badania i rozwój zaliczane są - obok regulacji prawnych, systemu edukacji czy dostępności finansowania przedsiębiorstw innowacyjnych - do najważniejszych czynników determinujących innowacyjność gospodarki. Znaczenie ma ich struktura (podmiotowa i przedmiotowa) oraz wielkość (Czerniak 2013, s. 49).

Działalność badawczo-rozwojowa może być finansowana przez podmioty należące do pięciu sektorów: rządowego, przedsiębiorstw, szkolnictwa wyższego, 
organizacji non-profit oraz zagranicznego (OECD 2010, s. 62). Analiza źródeł finansowania B+R w Polsce wskazuje, że w latach 2010-2015² dominował pod tym względem sektor rządowy (wykres 1). Jego udział w strukturze finansowania działalności badawczo-rozwojowej sukcesywnie się jednak zmniejszał. W badanym okresie nastąpił spadek o 19,1 pp. - z 60,9\% w 2010 roku do 41,8\% w 2015 roku. Odwrotną tendencję wykazywał sektor przedsiębiorstw, którego udział w 2010 roku wynosił 24,4\%, a w latach 2014-2015 - 39\% (zmiana o 14,6 pp.). W konsekwencji sektor rządowy w 2015 roku przewyższał sektor przedsiębiorstw o 2,8 pp., względem 36,5 pp., które dzieliły wymienione sektory w pierwszym roku analizowanego okresu.

Wykres 1. Struktura nakładów na B+R w Polsce w latach 2010-2016 według źródeł finansowania

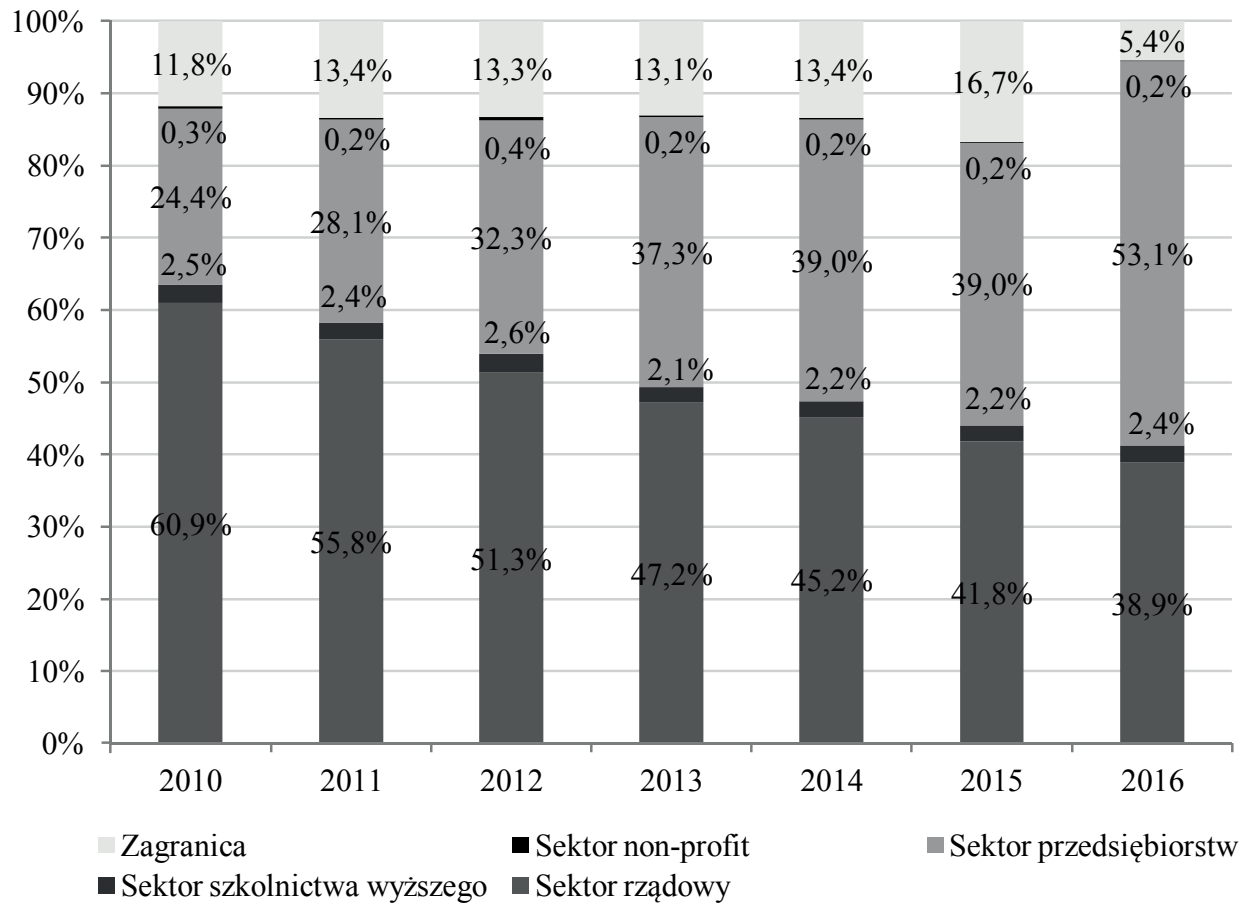

Źródło: opracowanie własne na podstawie danych Eurostatu.

Istotne źródło finansowania działalności B+R w Polsce stanowią także środki pochodzące z zagranicy. Sektor ten w latach 2010-2015 posiadał udział w strukturze od 11,8\% (2010) do 16,7\% (2015). W latach 2011-2014 udział był względnie stały i mieścił się w przedziale 13,1-13,4\%; najbardziej znacząca zmiana zaszła w roku 2015 - wzrost o 3,3 pp. w porównaniu z rokiem poprzednim. Do sektorów

\footnotetext{
${ }^{1}$ Na wykresach 1 i 3 uwzględniono także dane za rok 2016, jednak ze względu na zmianę wytycznych metodycznych nie są one w pełni porównywalne z latami poprzednimi (GUS 2017, s. 9).
} 
o mniejszym znaczeniu należą szkolnictwo wyższe, odpowiadające w badanym okresie za 2,1-2,6\% ogółu źródeł finansowania, oraz sektor non-profit z udziałem w strukturze na poziomie $0,2-0,4 \%$.

Jeśli chodzi o źródła finansowania, to struktura podmiotowa nakładów na $\mathrm{B}+\mathrm{R}$ w Unii Europejskiej w latach 2010-2016 cechowała się dużą stabilnością - zmiany udziałów poszczególnych sektorów były niewielkie (wykres 2 ). Widoczna jest wyraźna przewaga sektora przedsiębiorstw, z udziałem mieszczącym się w przedziale od 53,8\% (2010) do 56,6\% (2016). Największa zmiana w stosunku do roku poprzedniego zaszła w roku 2016 - wzrost o 1,3 pp., a zmiany w latach 2011-2015 nie przekraczały $0,3 \mathrm{pp}$. Udział sektora rządowego w UE oscylował w przedziale 31,3-34,8\% i charakteryzował się regularnym spadkiem - najwyższym w 2011 roku (o 1,5 pp.). W badanym okresie stale zwiększał się dystans dzielący oba sektory - w pierwszym roku wynosił $19 \mathrm{pp}$., a na koniec okresu 25,7 pp.

Źródła finansowania pochodzące z zagranicy stanowiły w krajach UE w analizowanym okresie średnio 8,9-10,8\% całości nakładów na B+R. Ich udział w każdym roku cechował się przyrostem w stosunku do roku ubiegłego. Pozostałe dwa sektory, szkolnictwa wyższego i non-profit, podobnie jak w Polsce, nie miały znaczącego udziału w finansowaniu działalności badawczo-rozwojowej. Kształtował się on w latach 2010-2016 odpowiednio na poziomie $0,8-0,9 \%$ oraz $1,6-1,7 \%$.

Wykres 2. Struktura nakładów na B+R w UE w latach 2010-2016 według źródeł finansowania

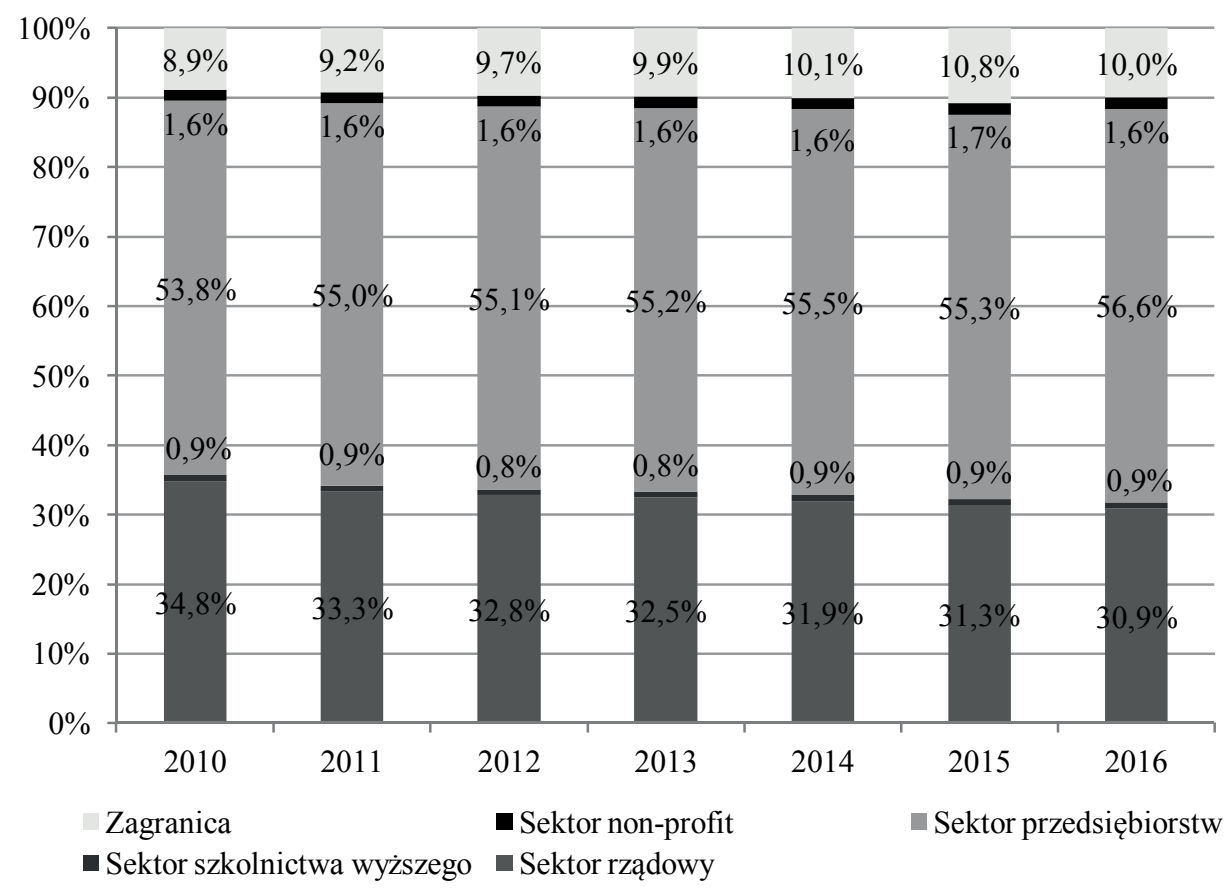

Źródło: opracowanie własne na podstawie danych Eurostatu. 
Analizując strukturę nakładów na $\mathrm{B}+\mathrm{R}$ w Polsce według sektorów wykonawczych, można zauważyć, że w latach 2010-2015 zaszły istotne zmiany w udziałach poszczególnych sektorów (wykres 3). Wyróżnić można dwa podokresy: lata 2010-2012, kiedy sektor rządowy i sektor szkolnictwa wyższego z łącznym udziałem w strukturze na poziomie $62,4-73,1 \%$ wyraźnie dominowały nad sektorem przedsiębiorstw, oraz lata 2013-2015, gdy te dysproporcje znacznie się zmniejszyły. W badanym okresie udział sektora przedsiębiorstw wzrósł o 20 pp., a najwyższy przyrost roczny, o 7,1 pp., przypadł na rok 2012. Odwrotne tendencje wykazywały sektory rządowy oraz szkolnictwa wyższego, których udział w całym okresie zmniejszył się odpowiednio o 11,5 i $8,3 \mathrm{pp}$. W wyniku tych zmian udział sektora przedsiębiorstw stał się najbardziej znaczący w strukturze nakładów wewnętrznych na $\mathrm{B}+\mathrm{R}$ (46,6\% w latach 2014-2015). Rola sektora non-profit była marginalna - wartość jego nakładów nie przekraczała $0,4 \%$ ogółu.

Wykres 3. Struktura nakładów na B+R w Polsce w latach 2010-2016 według sektorów wykonawczych

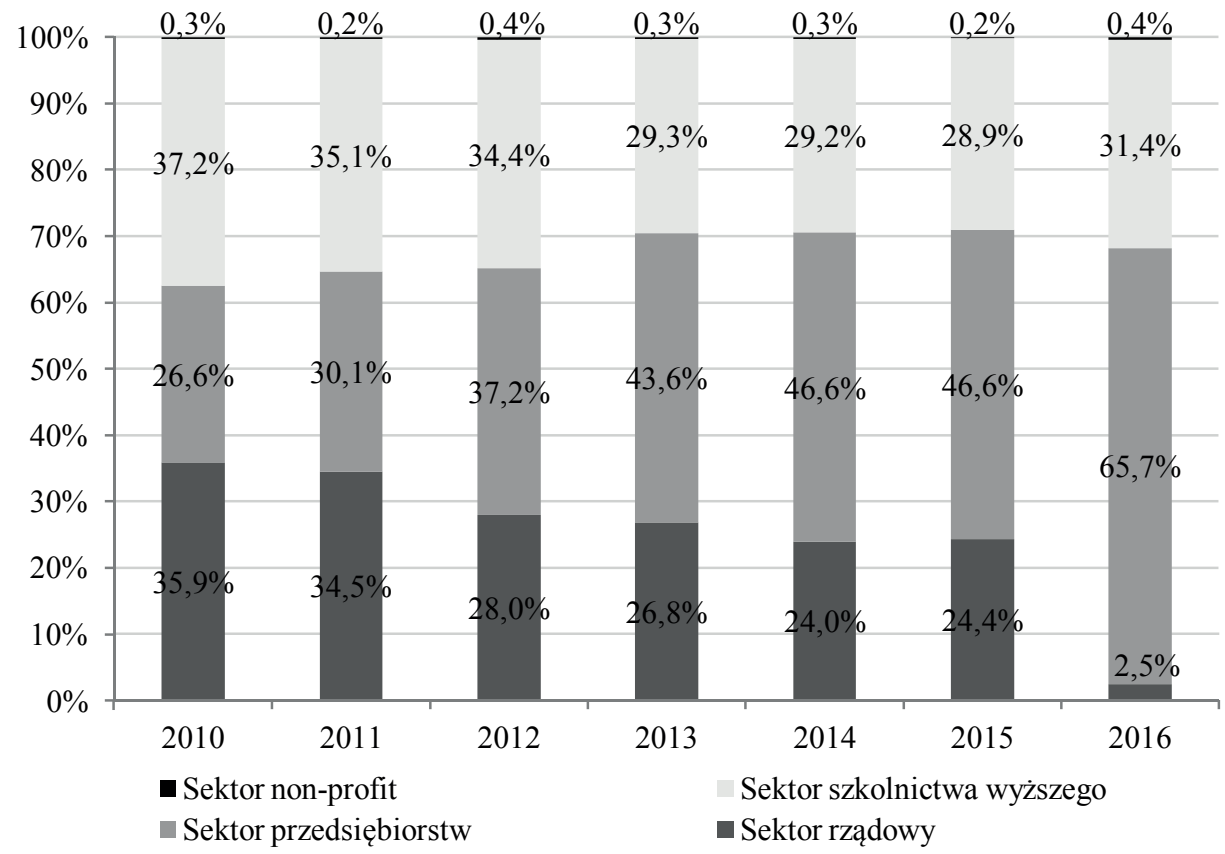

Źródło: opracowanie własne na podstawie danych Eurostatu.

W Unii Europejskiej w latach 2010-2016 przewaga sektora przedsiębiorstw nad pozostałymi sektorami była niekwestionowana. Jego udział mieścił się w przedziale $61,9-65,2 \%$, w każdym roku ponad dwukrotnie przewyższając udział sektora szkolnictwa wyższego oraz około pięciokrotnie - sektora rządowego (wykres 4). Wymienione sektory odpowiadały kolejno za $22,8-24,2 \%$ oraz 
$11,2-12,9 \%$ nakładów wewnętrznych w UE, a organizacje non-profit za $0,8-1 \%$. Analogicznie do struktury źródeł finansowania zestawienie sektorów wykonawczych w kolejnych latach cechowały duża regularność i zmiany udziałów na nieznacznym poziomie.

Wykres 4. Struktura nakładów na B+R w UE w latach 2010-2016 według sektorów wykonawczych



Źródło: opracowanie własne na podstawie danych Eurostatu.

Zestawienie danych dotyczących struktury nakładów na działalność badawczo-rozwojową z podziałem na sektory wykonawcze w Polsce i UE pozwala zauważyć, że przeciętny udział sektora przedsiębiorstw w krajach Unii Europejskiej był zdecydowanie wyższy niż w Polsce. Różnica ta jednak systematycznie się zmniejszała, od 35,3 pp. w 2010 roku do 17,7 pp. w 2015 roku. Kierunek zmian zachodzących w strukturze podmiotowej nakładów wewnętrznych w Polsce wskazywał na dostosowywanie się do średniej unijnej. Obok zyskującego na znaczeniu sektora przedsiębiorstw zmniejszał się udział sektorów rządowego oraz szkolnictwa wyższego. W 2015 roku udział nakładów szkolnictwa wyższego zbliżył się do średniej UE (28,9\% w stosunku do $23,1 \%)$, a sektor rządowy przewyższał ją ponaddwukrotnie (24,4\% wobec przeciętnego udziału w UE na poziomie $11,7 \%)$. 


\section{Nakłady sektora przedsiębiorstw na działalność badawczo-rozwojową}

Wydatki na działalność badawczo-rozwojową informują o intensywności jej prowadzenia przez określone podmioty. Do pomiaru nakładów na $\mathrm{B}+\mathrm{R}$ w skali gospodarki najczęściej stosuje się wskaźnik GERD (gross expenditures on research and development). Stanowi on sumę nakładów wewnętrznych przeznaczonych na działalność badawczo-rozwojową przez wszystkie jednostki w danym kraju i roku. Wskaźnik odnosi się do wielkości PKB i wyraża odsetek środków inwestowanych w prace $\mathrm{B}+\mathrm{R}$. W krajach rozwiniętych bardzo istotnym składnikiem nakładów badawczych są wydatki przedsiębiorstw (BERD - Business Expenditures on $R \& D)$ (Geodecki 2014, s. 50-51).

$\mathrm{Na}$ wielkość wydatków na $\mathrm{B}+\mathrm{R}$ wpływa wiele czynników. Do najważniejszych można zaliczyć (Janasz 2005, s. 240-241):

1. strukturę gospodarki oraz eksportu - ważny jest udział przedsiębiorstw sektora przemysłu przetwórczego (szczególnie wysokiej techniki) w eksporcie, a także struktura firm pod względem wielkości; duże przedsiębiorstwa inwestują w $\mathrm{B}+\mathrm{R}$ znacznie więcej niż małe i średnie;

2. instrumenty podatkowe, takie jak stopy amortyzacji prac $\mathrm{B}+\mathrm{R}$, inwestycji związanych z $\mathrm{B}+\mathrm{R}$ oraz ulgi podatkowe, które wynikają z prowadzenia takiej działalności;

3. odsetek pracowników z wyższym wykształceniem w ogólnej liczbie zatrudnionych - przyjmuje się, że wzrost zatrudnienia absolwentów wyższych uczelni, którzy mają doświadczenie w pracy badawczej, powoduje zwiększenie popytu na $\mathrm{B}+\mathrm{R}$ w długim okresie;

4. rodzaj polityki technologicznej, nastawienie na absorpcję nowych wyrobów, usług, wiedzy i procesów technologicznych lub wykorzystanie posiadanej już wiedzy i technologii.

W latach 2007-2016 można było zauważyć w Polsce, podobnie jak w Unii Europejskiej, tendencję wzrostową, jeśli chodzi o wskaźnik GERD/PKB (wykres 5). W 2007 roku nakłady na B+R w Polsce wynosiły 0,56\% PKB, a na koniec badanego okresu - 0,97\%, co przekłada się na wzrost o $73,2 \%$. W przypadku Unii Europejskiej zmiana ta wynosiła $14,7 \%$ (GERD/PKB na poziomie $1,77 \%$ w 2007 i 2,03\% w 2016 roku). Wskaźnik osiągnął maksymalny poziom w roku 2015 - 2,04\% (UE) i 1\% (Polska), rok później miała miejsce niewielki regres, odpowiednio o 0,01 i $0,03 \mathrm{pp}$.

Należy zwrócić uwagę na to, że w latach 2007-2016 sukcesywnie zmniejszał się dystans pomiędzy wartościami wskaźnika Polski i UE - na początku tego okresu nakłady na działalność badawczo-rozwojową w Unii Europejskiej w relacji do PKB były ponad trzy razy większe niż w Polsce, jednak w roku 2016 nieznacznie przekraczały ich dwukrotność. Odnosząc dane z ostatniego roku badanego okresu do celów strategii „Europa 2020”, można stwierdzić, że średnia unijna wynosi 
67,7\% zakładanych 3\% PKB, a wskaźnik w przypadku Polski stanowi 57,1\% krajowego celu na poziomie $1,7 \%$ PKB.

Wykres 5. Nakłady wewnętrzne na B+R w Polsce i UE w latach 2007-2016 (\% PKB)

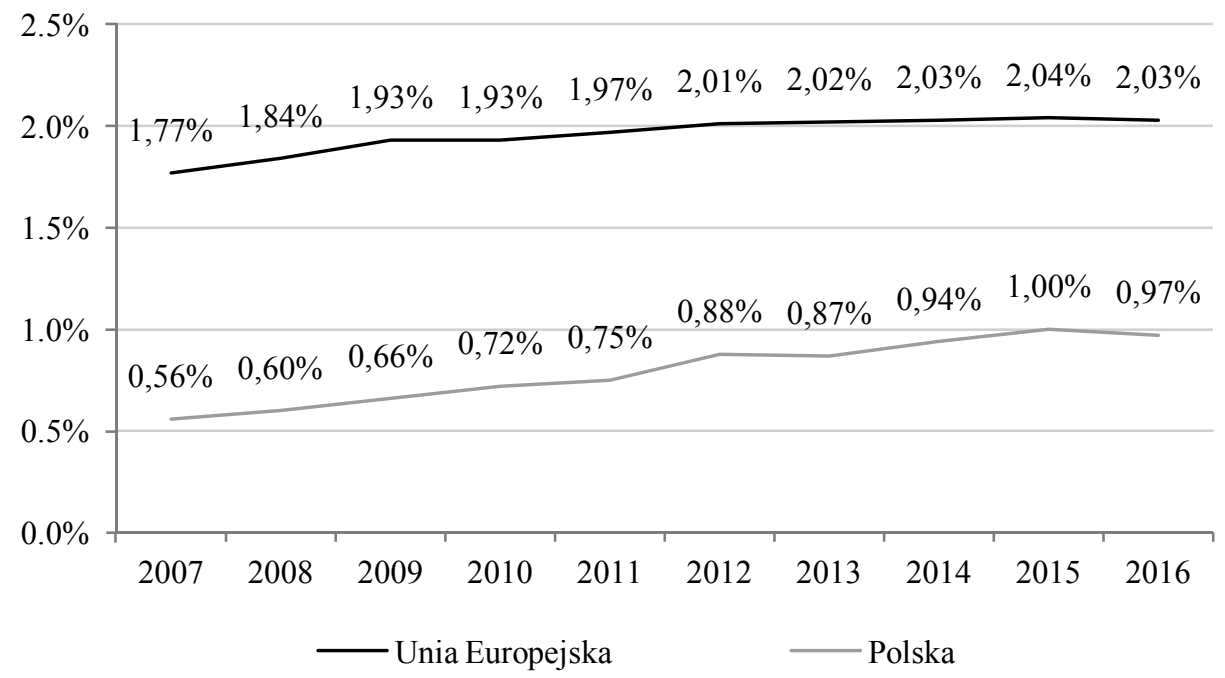

Źródło: opracowanie własne na podstawie danych Eurostatu.

Pomimo znaczącego wzrostu udziału nakładów na badania oraz prace rozwojowe w PKB Polska pozostaje w gronie krajów UE o najniższych wartościach wskaźnika (wykres 6). W 2016 roku zajmowała 20. pozycję spośród 28 państw członkowskich UE. Niższe nakłady na B+R w relacji do PKB były w Chorwacji $-0,85 \%$, na Litwie $-0,85 \%$ i Słowacji - 0,79\%, w Bułgarii - 0,78\%, na Malcie - $0,61 \%$ i Cyprze $-0,50 \%$, w Rumunii $-0,48 \%$ oraz na Łotwie $-0,44 \%$. Krajem o najwyższej wartości wskaźnika GERD/PKB w Unii Europejskiej - 3,25\% była Szwecja. Należała ona, obok Austrii (3,09\%), do krajów, w których nakłady na działalność badawczo-rozwojową przekroczyły poziom 3\% PKB. Kolejne miejsca zajmowały: Niemcy $-2,94 \%$, Dania $-2,87 \%$, Finlandia $-2,75 \%$, Belgia $-2,49 \%$ oraz Francja $-2,25 \%$.

Widoczne jest wyraźne zróżnicowanie pomiędzy krajami tzw. „starej” i „nowej" Unii. Wszystkie wymienione kraje o najwyższej relacji GERD w stosunku do PKB tworzyły Unię Europejską przed przyjęciem nowych członków w 2004 roku, a wśród krajów, w których wskaźnik ten jest najniższy, znajdują się wyłącznie przedstawiciele „nowej” UE. 
Wykres 6. Nakłady wewnętrzne na B+R w krajach UE w roku 2016 (\% PKB)

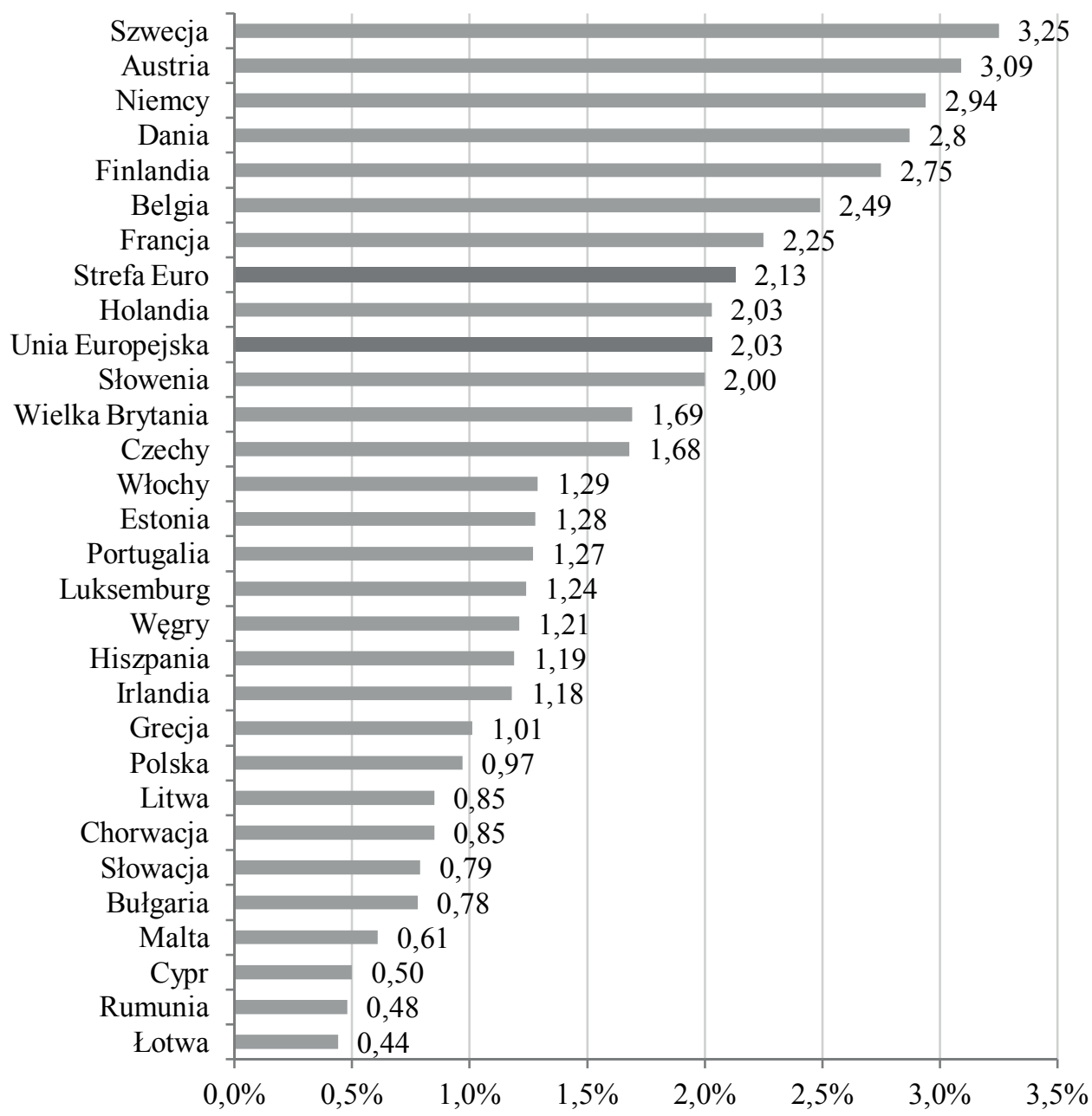

Źródło: opracowanie własne na podstawie danych Eurostatu.

Nakłady wewnętrzne na działalność badawczo-rozwojową sektora przedsiębiorstw w Polsce w latach 2007-2016 zwiększyły się o 481,6\%. W roku 2007 ich wartość przekraczała nieco 2 mld zł, a w roku 2016 było to już ponad 11,7 mld zł (wykres 7). Najbardziej intensywny wzrost nakładów przedsiębiorstw przypada na lata 2011-2012, kiedy to zmiana procentowa w porównaniu z rokiem ubiegłym wynosiła odpowiednio 27\% i 51,6\%, a także na rok 2016 - wzrost o 41,1\%. Nakłady ogółem w latach 2007-2016 także wykazywały tendencję wzrostową, wyjątek stanowił jedynie rok 2016, w którym nastąpił spadek o 0,7\% - z 18,061 mld zł do 17,943 mld zł. Taki poziom nakładów na $\mathrm{B}+\mathrm{R}$ w ostatnim roku analizowanego okresu spowodował wyraźną dominację sektora przedsiębiorstw nad pozostałymi 
sektorami wykonawczymi. O działalności badawczo-rozwojowej przedsiębiorstw w Polsce pozytywnie świadczy znaczne zwiększenie wartości ich nakładów, pomimo odwrotnego kierunku wartości nakładów ogółem.

Wykres 7. Nakłady wewnętrzne ogółem oraz sektora przedsiębiorstw w Polsce w latach 2007-2016 (w mld zl)

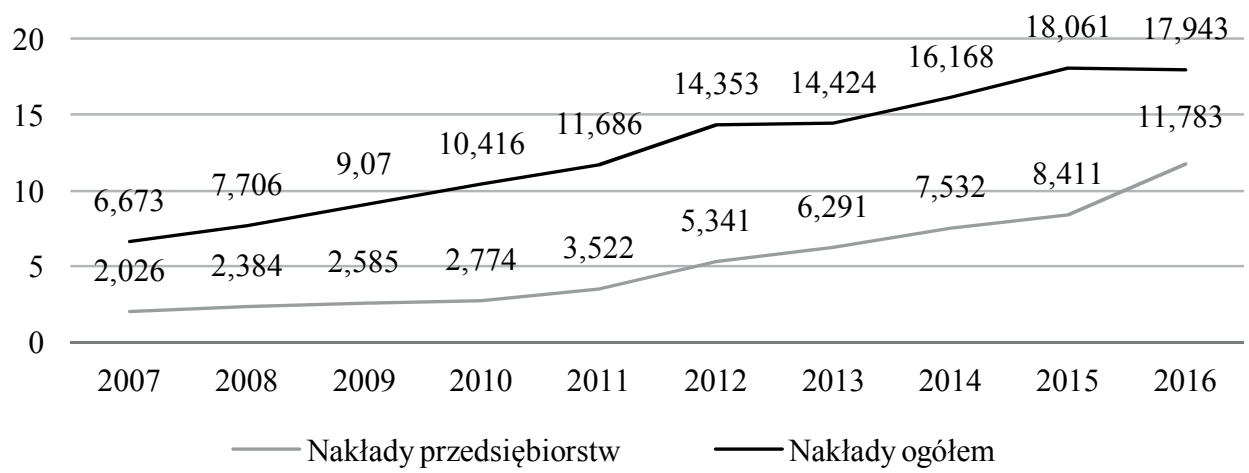

Źródło: opracowanie własne na podstawie danych Eurostatu.

Analizując nakłady na $\mathrm{B}+\mathrm{R}$ sektora przedsiębiorstw wyrażone w euro w przeliczeniu na jednego mieszkańca, można zauważyć znaczący dystans, jaki dzieli pod tym względem Polskę od średniej w Unii Europejskiej (wykres 8). Wskaźnik obliczony dla Polski w latach 2007-2016 przyjmował wartości od 14,0 (2007) do 71,1 euro (2016), co odpowiada zmianie, która zaszła w tym okresie, na poziomie 408\%. W tych samych latach średnia w krajach UE wynosiła 293,1 euro w 2007 roku i 385,4 euro w 2016 roku (zmiana o 31,5\%).

Wykres 8. Nakłady wewnętrzne przedsiębiorstw na B+R per capita w Polsce i UE w latach 2007-2016 (w euro)

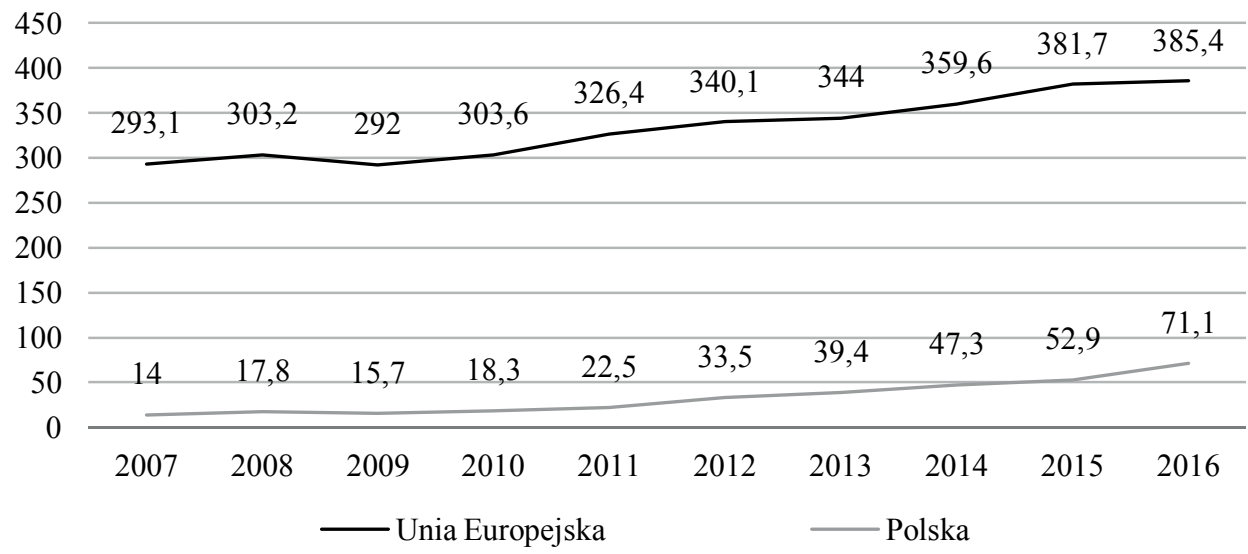

Źródło: opracowanie własne na podstawie danych Eurostatu. 
W badanym okresie widoczny jest stały wzrost wartości wskaźnika, z wyjątkiem roku 2009, kiedy to nastąpiło jego obniżenie. W Polsce był to spadek z 17,8 na 15,7 euro, czyli o 11,8\%, a w UE 292 euro w 2009 roku w stosunku do 303,2 euro w roku poprzednim (o $3,7 \%$ mniej).

Liderem wśród krajów Unii Europejskiej według kryterium wysokości nakładów na działalność badawczo-rozwojową przedsiębiorstw per capita w 2016 roku była Szwecja, podobnie jak w przypadku wartości wskaźnika GERD/PKB (wykres 9). Wartość BERD na jednego mieszkańca wynosiła tam 1069,5 euro. Następne pod tym względem były: Dania (918,8 euro), Austria (896,3 euro), Niemcy (764,5 euro), Finlandia (711 euro) i Belgia (648,2 euro).

Wykres 9. Nakłady wewnętrzne przedsiębiorstw na B+R per capita w krajach UE w roku 2016 (w euro)

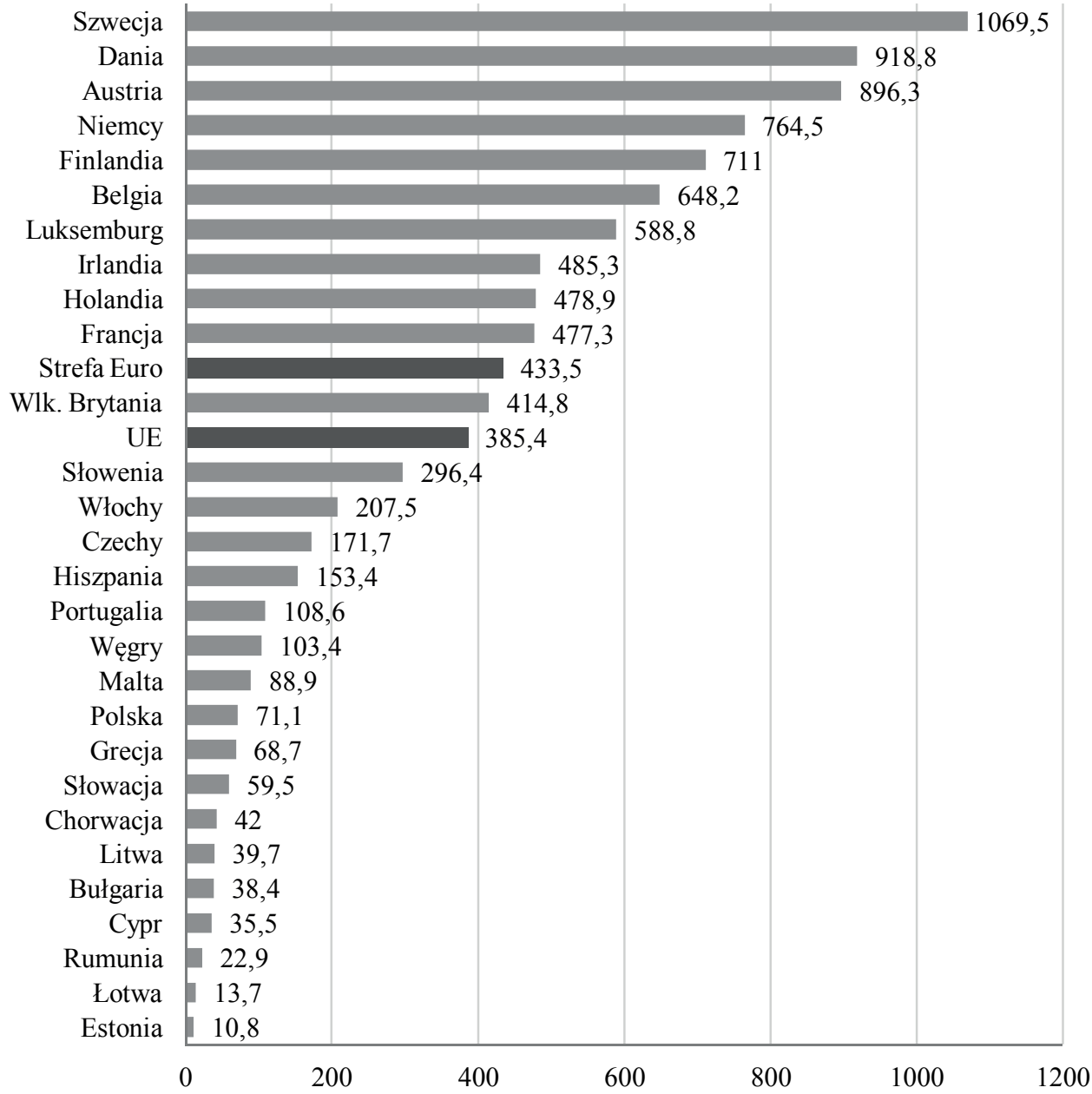

Źródło: opracowanie własne na podstawie danych Eurostatu. 
Na uwagę zasługuje ewidentne zróżnicowanie wartości wskaźnika pomiędzy poszczególnymi krajami należącymi do Unii Europejskiej. W Estonii nakłady sektora przedsiębiorstw na $\mathrm{B}+\mathrm{R}$ w 2016 roku wyniosły w przeliczeniu na mieszkańca 10,8 euro, czyli prawie stukrotnie mniej niż w Szwecji. Wśród krajów o najniższych wynikach znajduje się również Łotwa (13,7 euro), Rumunia (22,9 euro), Cypr (35,5 euro), Bułgaria (38,4 euro), Litwa (39,7 euro) i Chorwacja (42 euro). Są to wartości wielokrotnie mniejsze od średniej UE, w przypadku Chorwacji dziewięciokrotnie, zaś Łotwa wykazywała wynik 28 razy niższy.

Polska należała do krajów, w których BERD na jednego mieszkańca nie przekracza 100 euro; w 2016 roku było to 71,1 euro. Najbardziej zbliżone wyniki miały Grecja - 68,7 euro oraz Malta - 88,9 euro. Biorąc pod uwagę jedynie kraje Grupy Wyszehradzkiej, z którymi Polska jest często porównywana, można zauważyć, że niższe nakłady przedsiębiorstw odnotowano na Słowacji (50,5 euro), a wyższe na Węgrzech (103,4 euro) i w Czechach (171,1 euro). Czechy oraz Słowenia, gdzie wskaźnik BERD per capita kształtował się na poziomie 296,4 euro, były w 2016 roku krajami o najwyższych nakładach sektora przedsiębiorstw w Europie Środkowo-Wschodniej.

\section{Podsumowanie}

Udział sektora przedsiębiorstw w finansowaniu działalności badawczo-rozwojowej - a także sektory wykonawcze - w Polsce w latach 2010-2015 wyraźnie wzrastał. Do 2015 roku charakterystyczny dla struktury nakładów wewnętrznych był duży udział sektora rządowego, który, chociaż regularnie się zmniejszał, wciąż pozostawał na poziomie wyższym niż przeciętny w Unii Europejskiej. Sposób kształtowania się udziałów poszczególnych sektorów pozwala oczekiwać, że struktura nakładów na badania naukowe i prace rozwojowe w kolejnych latach będzie się zbliżać do średniej krajów UE.

Warto podkreślić, że w latach 2007-2016 nastąpił w Polsce dynamiczny wzrost nakładów wewnętrznych na działalność B+R. Trend ten należy ocenić pozytywnie, jednak pomimo zmian w wysokości nakładów oraz w ich strukturze, wartości wskaźników takich jak GERD/PKB czy BERD per capita wskazywały, że Polska znajduje się wśród najmniej innowacyjnych krajów Unii Europejskiej, zdecydowanie poniżej średniej unijnej. Na uwagę zasługuje tempo, w jakim zwiększały się nakłady przedsiębiorstw - porównując rok 2016 z rokiem 2007, można zauważyć, że był to wzrost o ponad $481 \%$. Jednak w ujęciu nominalnym dystans, który dzielił pod tym względem Polskę od krajów UE o przeciętnych wynikach, a szczególnie od krajów, które przewodziły w zestawieniach, pozostawał znaczący. 


\section{Bibliografia}

Barańska-Fischer M. (red.), Blażlak R., Szymański G. (2016), Innowacje w biznesie. Wybrane zagadnienia, Wydawnictwo Politechniki Łódzkiej, Łódź.

Czerniak J. (2013), Polityka innowacyjna w Polsce. Analiza i proponowane kierunki zmian, Difin, Warszawa.

Dolińska M. (2010), Innowacje w gospodarce opartej na wiedzy, Polskie Wydawnictwo Ekonomiczne, Warszawa.

Eurostat, Intramural $R \& D$ expenditure (GERD) by sectors of performance, http:// appsso.eurostat.ec.europa.eu/nui/show.do?dataset=rd_e_gerdtot\&lang=en (data dostępu: 3.04.2018).

Eurostat, Intramural R\&D expenditure (GERD) by source of funds, http://appsso. eurostat.ec.europa.eu/nui/show.do?dataset=rd_e_fundgerd\&lang=en (data dostępu: 3.04.2018).

Gasz M. (2014), Strategia Europa 2020 - założenia i perspektywy realizacji, „Nierówności społeczne a wzrost gospodarczy”, nr 38 (2).

Geodecki T. (2014), Metodyka pomiaru działalności innowacyjnej (w:) Geodecki T., Mamica Ł. (red.), Polityka innowacyjna, Polskie Wydawnictwo Ekonomiczne, Warszawa.

GUS (2017), Działalność badawcza i rozwojowa w Polsce w 2016 r., https://stat. gov.pl/files/gfx/portalinformacyjny/pl/defaultaktualnosci/5496/15/1/1/dzialalnosc_badawcza_i_rozwojowa_w_polsce_w_2016_r.pdf (data dostępu: 1.12.2018).

Janasz W. (2005), Zmiany aktywności innowacyjnej Polski w okresie transformacji (w:) Janasz W. (red.), Innowacje $w$ działalności przedsiębiorstw w integracji z Unia Europejska, Difin, Warszawa.

Jasiński A.H. (2014), Innowacyjność polskiego przemystu, 2006-2012: Byt postęp czy nie? (w:) Kamińska A. (red.), Innowacyjność. Uwarunkowania, strategie, wyzwania, Placet, Warszawa.

Knosala R., Boratyńska-Sala A., Jurczyk-Bunkowska M., Moczała A. (2014), Zarzadzanie innowacjami, Polskie Wydawnictwo Ekonomiczne, Warszawa.

Komisja Europejska (2010), Europa 2020. Strategia na rzecz inteligentnego i zrównoważonego rozwoju sprzyjajacego właczeniu społecznemu, Bruksela.

OECD (2010), Podręcznik Frescati 2002. Proponowane procedury standardowe dla badań statystycznych $w$ zakresie działalności badawczo-rozwojowej, Ministerstwo Nauki i Szkolnictwa Wyższego.

Tidd J., Bessant J. (2011), Zarządzanie innowacjami. Integracja zmian technologicznych, rynkowych i organizacyjnych, Wolters Kluwer, Warszawa.

Weresa M.A. (2014), Polityka innowacyjna, Wydawnictwo Naukowe PWN, Warszawa.

Żmuda M. (2011), Strategia Europa 2020 jako plan rozwoju spoteczno-gospodarczego Unii Europejskiej, „Ekonomia” nr 4(16). 


\section{Streszczenie}

We współczesnej gospodarce innowacyjność, zarówno na poziomie państw, jak i przedsiębiorstw, ma istotne znaczenie. Jest to czynnik znacząco wpływający na koniunkturę i rozwój gospodarczy. Do najważniejszych mierników poziomu innowacyjności zalicza się wskaźniki dotyczące działalności badawczo-rozwojowej. Ze względu na swoją istotę działalność badawczo-rozwojowa odgrywa kluczową rolę w przedsiębiorstwach. Celem artykułu jest analiza struktury i wielkości nakładów na działalność badawczo-rozwojową w Polsce, ze szczególnym uwzględnieniem sektora przedsiębiorstw, w odniesieniu do Unii Europejskiej.

Słowa kluczowe: działalność badawczo-rozwojowa, przedsiębiorstwo, Unia Europejska

\section{Summary}

Research and development in Polish enterprises against the background of the European Union

In the modern economy, innovation, at both the state and the enterprise level, is important. It is a factor that has a significant influence on the economic situation and development. The most important measures of the level of innovation include indicators concerning research and development activity. Due to their essence, $\mathrm{R} \& \mathrm{D}$ has a key role in enterprises. The purpose of the article is to analyse the structure and volume of expenditures on research and development in Poland, in relation to the European Union, with particular emphasis on the enterprise sector.

Keywords: research and development activity, enterprise, European Union JEL: O31, O32, O39 